\title{
The Effect of Endosulfan in GnRH and G+H Genes Expression of Male Hard-Lipped Barb (Osteochilus vittatus C.V.)
}

\author{
Asrul Sahri Siregar ${ }^{1}$, Pudji Astuti ${ }^{2}$, Yulia Sistina ${ }^{3}$ and Norman Arie Prayogo ${ }^{1 *}$
}

'Fishery and Marine Faculty, Jenderal Soedirman University, Purwokerto, Indonesia

${ }^{2}$ Animal Medicine Faculty, Gadjah Mada University, Yogyakarta, Indonesia

${ }^{3}$ Biology Faculty, Jenderal Soedirman University, Purwokerto, Indonesia

*Corresponding author email : norman_s2biologi@yahoo.com

Received November 21, 2019; Accepted July 02, 2020; Available online November 20, 2020

\begin{abstract}
The presence of pollutants in water makes the environment toxic to all living biota and affects reproduction in fish. One of such pollutants is endosulfan, which is an off-patent organochlorine insecticide, widely used in various agricultural activities. Endosulfan is extremely toxic to fish and all other aquatic organisms, showing a range of chronic effects, including genotoxicity, and reproductive issues. Therefore, the aim of the research was to find the effect of endosulfan on $\mathrm{cGnRH}, \mathrm{sGnRH}, \mathrm{GHH}-\mathrm{I}$ and $\mathrm{GHH}$-II gene expression in male hard-lipped barb fish. These fish were kept in aquarium containing several levels of endosulfan $(0$ $\mathrm{mg} / \mathrm{L}$ [control]; $0.88 \mathrm{mg} / \mathrm{L}$ [low level]; $1.76 \mathrm{mg} / \mathrm{L}$ [medium level]; and $2.64 \mathrm{mg} / \mathrm{L}$ [high] level) for 60 days. The effects of endosulfan on $\mathrm{GnRH}$ performance on the fish were evaluated by the expressions of these genes; cGnRH-II, sGnRH, GHH-I, and GHH-II. In the 8th week, there was a decrease in the expression of all the four genes in fish with high dose of endosulfan compared with the control group $(P<0.05)$. These findings showed that endosulfan inhibits the expression of cGnRH, sGnRH, G+H-I and G+H-Il genes in male hardlipped barb.
\end{abstract}

Keyword: endosulfan, gene expression, male lipped barb

\section{INTRODUCTION}

Globally, pesticides and agrochemicals are important components in agricultural systems, which have significantly increase crop yields and food production (Carvalho, 2017). However, the increase in the use of pesticides is a major concern due to its negative impact on the environment and could even be harmful to humans if not well managed (Ditjen PSP, 2016, and Sukardi et al., 2019).

One of the pesticides is endosulfan, an organochlorines (OCP) compound registered by Stockholm Conservation (Astoviza, Cappelletti, Bilos, Migoya, \& Colombo, 2016), as persistent organic pollutants (POPs), hence, stopped its production and use globally (Du, et al., 2015). However, the residues of the pesticide have been found in various foods across different geographical locations (Weber, et al., 2010). The study implied that a large number of ecosystems are exposed to endosulfan through the food chain. This is part of the organochlorine pesticides included in the most dangerous persistent organic pollutants (Guo et al., 2017), with the empirical formula, $\mathrm{C}_{9} \mathrm{H}_{6} \mathrm{Cl}_{6} \mathrm{O}_{3} \mathrm{~S}$ (Thangadurai \& Suresh, 2014; Chatteriee, 2016).
According to Piazza, Pandolfi, \& Lo Nostro (2011), endosulfan is slightly soluble in water but soluble in organic solvents. It reaches water bodies due to runoff from agricultural areas with concentrations ranging from 0.01 to $2.5 \mathrm{mg} / \mathrm{L}$ (Ballesteros et al., 2014). Some researchers have examined the presence of its residues in the environment and found it to be toxic to aquatic organisms including fish and the aquatic environment in general (Watts, 2012). Endosulfan, as a new member of persistent organic pollutants, has been shown to induce reproductive dysfunction in various animals (Du et al., 2015). According to Han, Jiao, Kong, Shan, \& Zhang (2011), it has the ability to undergo bioaccumulation and biomagnification processes through the food chain.

Fish exposed to water polluted by this pollutant in sub-lethal concentrations absorb it through the gill membrane, curricular diffusion, food and direct absorption from sediments. Once fish absorbs its residues in water, it accumulates in the body's tissues because endosulfan is an organochlorine insecticide group with high lipophility properties, hence, interfering with the physiological processes and 
metabolic activities of the fish (Taufik \& Setiadi, 2015).

Endosulfan is very toxic to all aquatic organisms, showing chronic effect on the aquatic lives in reproductive and developmental degeneration (Watts, 2012, and Rehman et al., 2016). According to Chakrabarty et al. (2012), the pesticide causes a decrease in GnRH activity and an increase in ovarian aromatase activity of catfish (Clarias batrachus). Through some environmental factors, the hypothalamus stimulates the production of $\mathrm{GH}$ s from the pituitary gland, and $\mathrm{GnRH}$ regulates $\mathrm{GHH}$ secretion. Then, $\mathrm{G}+\mathrm{H}$ stimulates the production of steroid hormones in the gonads (Piazza, Pandolfi, Da Cuña, Genovese, \& Lo Nostro, 2015, Sukardi et al.,2016). Additionally, the endocrine disruption chemicals (EDC) have the capacity of altering fish steroid hormones, which in turn affect the workings of the hypothalamus (Bashir, 2019; Wu, He, Zhang, Jiang, \& Zhang, 2012). Hormonal interactions between the hypothalamus and gonads are very important in sexual differentiation in several fish species (Pandolfi et al., 2006). Thus, endosulfan has a mechanism through which it disturbs fish by inhibiting its hypothalamic tryptophan hydroxylase activity. These result in the high rate of serotonin synthesis which disrupts the GnRH nerve (Gore and Crews, 2009). The evidence of inhibition of $\mathrm{GnRH}$ by endosulfan was illustrated in a study of Cichlasoma fish, which was continuously exposed to this substance for 3 months and showed a significant decrease in GnRH II activity. This decrease in activity resulted in the inhibition of $\mathrm{GHH}$ release in the pituitary (Piazza et al., 2015). Furthermore, endosulfan has the capacity of mimicking sex steroids by damaging the function of HPG as the main regulator (sGnRH which regulates and releases $\mathrm{GHH}$ ) (Yoon, Kwackb, Kimc, \& Leec, 2014).

Based on this background, the general objective of this research was to determine the mechanism of endosulfan inhibition on the reproductive system of hard-lipped barb fish (Osteochilus vittatus C.V.). The specific purpose was to find out the effects of endosulfan disturbance (EDC) on the hypothalamic (cGnRH and sGnRH) and pituitary organs ( $\mathrm{GHH}-\mathrm{I}$, $\mathrm{G}+\mathrm{H}-\mathrm{II})$ of male hard-lipped barb fish.

\section{EXPERIMENTAL SECTION}

This is an experimental research, which involves the study of variables whose data do not yet exist. Hence, the need to manipulate the process by providing certain treatments to the research subjects which are then observed and measured for their impacts. The experimental design in this study was a Completely Randomized Design (CRD) with 4 treatments of endosulfan concentrations given to 3 male fish for 60 days and sampling carried out every two weeks. The given treatments are as follows; P0: 0 $\mathrm{ppb}$ concentration of endosulfan; P1: $0.88 \mathrm{ppb}$ concentration of endosulfan; P2: $1.76 \mathrm{ppb}$ concentration of endosulfan and P3: $2.64 \mathrm{ppb}$ concentration of endosulfan. Then, there was a molecular observation of the research parameters such as $c \mathrm{GnRH}$, sGnRH, G+H-I, and $\mathrm{GH}-\mathrm{H}-\mathrm{ll}$ hormones.

The process involved the use of 4 round fiber tubs as the maintenance containers $(d=127 \mathrm{~cm}, t=60$ $\mathrm{cm}$ ) filled with $380 \mathrm{~L}$ of water at a height of $30 \mathrm{~cm}$. Before being used, the tubs were soaked in $20 \mathrm{mg} / \mathrm{L}$ of $\mathrm{KMnO} 4$ (PK) as a disinfectant. Aeration and recirculation system were made in the tubs to maintain the quality of used in raising the fish. These were six-month-old fish with a total length of 9-11 $\mathrm{cm}$ and a weight of 7-12 grams, allowed to acclimatize for 7 days (1 week) (Siregar, Prayogo, \& Sulistyo, 2018).

The formulations of endosulfan insecticide used was Akodan $35 \mathrm{EC}$, equivalent to a concentration of $350,000 \mathrm{mg} / \mathrm{L}$ of endosulfan. Then, a $10 \mathrm{ppm}$ endosulfan stock solution was prepared by dissolving $2.86 \mathrm{~mL}$ of Akodan $35 \mathrm{EC}$ in $10 \mathrm{~mL}$ of aceton p.a., then added to $100 \mathrm{~mL}$ of water. The concentration of the treatment was obtained through gradual dilution formula. The concentration of the test solution was determined using the dilution formula: $\mathrm{V} 1 \times \mathrm{N} 1=\mathrm{V} 2$ x N2 (Siregar et al., 2018).

The 3 hard-lipped barb fish in each treatment were randomly selected from the stock, anesthetized, and the head separated from the body, by cutting behind the operculum. The head was placed facing up and sliced horizontally near the nostril. The severed bone was separated from the brain to reveal the turcica. Then the hypothalamus and pituitary glands were isolated using an ear pick. These two glands were weighed with analytical scales, then inserted into a tube, which was stored in a freezer at $-80^{\circ} \mathrm{C}$ until the sample was isolated.

Further, the samples of these glands were taken with tweezers and weighed, as much as $25 \mathrm{mg}$ for each fish sample. Then, the RNA isolated using Total RNA Mini-Kit. This RNA isolation stage is usually conducted using the instructions contained in the catalog with the following processes: Cell Lysis, RNA Binding, RNA Washing, RNA Elution, DNAse Treatment (Prayogo, Siregar, \& Sukardi, 2016).

The Nano Spectrophotometer Implen was used to measure the RNA concentrations. Firstly, the tool was turned on, then set to measure the concentration, with the provisions of Lid Factor 10 in $\mathrm{mg} / \mathrm{mL}$ units. The tool immediately commenced the measurement after completing the tool setup, and having previously dripped blank (aquabidest) using a $4 \mu \mathrm{L}$ micropipette on the cuvette, and the sample green button pressed. The prepared sample taken with a $4 \mu \mathrm{L}$ micropipette, then dropped into the cuvette, while the green sample button was pressed. The escape key was selected till it returned to the start menu, after all samples have been measured (Prayogo et al., 2016). 
Table 1. Primers design used in Real-Time PCR

\begin{tabular}{cllcc}
\hline No & \multicolumn{1}{c}{ Primers Code } & \multicolumn{1}{c}{$\begin{array}{c}\text { DNA complementary sequence } \\
\text { (primer) }\end{array}$} & Tm & $\begin{array}{c}\text { PCR } \\
\text { product }\end{array}$ \\
\hline 1. & Forward Real-Time cGnRH (F3) & CAT CTG CAG GCT GTT TGT GG & 59.89 & 200 bp \\
2. & Reverse Real Time cGnRH (R3) & TGC TGA GAG CTG GCA AAC TG & 59.97 & \\
3. & Forward Real Time sGnRH (F3) & TGG TGT GTG TGT TGG AGG TT & 62.81 & 75 bp \\
4. & Reverse Real-Time sGnRH (R3) & AAT GTT GCC TCC ACT TCA CC & 62.83 & \\
5. & Reverse Real-Time GHH-I (R3) & CAT TGC AGC CGA GTG TCTG & 62.83 & 175 bp \\
6. & Forward Real-Time GHH-II (F3) & TGG ATG TGA AGG AGT GCA AAC & 59.89 & \\
7. & Forward Real-Time GHH-II (F3) & TGG ATG TGA AGG AGT GCA AAC & 59.89 & 200 bp \\
8. & Reverse Real Time GHH-II (R3) & CAT CAT TGA CAA GCA CCC GT & 59.97 & \\
9. & Forward Beta Actin (FA) & GAG CTA TGA GCT CCC TGA CGG & 58.3 & 53 bp \\
10. & Reverse Beta Actin (RA) & AAA CGC TCA TTG CCA ATG GT & 55.6 & \\
\hline
\end{tabular}

$\mathrm{A}=$ Adenine, $\mathrm{T}=$ Thymine, $\mathrm{C}=$ Cytosine, $\mathrm{G}=$ Guanine

Samples from each treatment were then evaluated for GnRH and GHH gene expression using KAPA ${ }^{\mathrm{TM}}$ SYBR ${ }^{\circledR}$ FAST One-Step qRT- PCR Kit (Prayogo et al., 2016). This commenced with the synthesis of complementary deoxyribonucleic acid (cDNA) at 42 ${ }^{\circ} \mathrm{C}$ for 5 minutes, then deactivating RT at $95{ }^{\circ} \mathrm{C}$ for 2 5 minutes. This was followed by the denaturation process at a temperature of $95^{\circ} \mathrm{C}$ for 3 seconds and annealing at a temperature of $60^{\circ} \mathrm{C}$ for 20 seconds by 40 cycles. Then, the last stage involved the extension process for 5 minutes. Specific real-time primers, which amplify the GnRH and G+H genes in male hard-lipped barb fish, were used in this study. These primers used to test the expression of $\mathrm{GnRH}$ and $\mathrm{GHH}$ were $\mathrm{F} 2$ or $\mathrm{F} 3$, as well as R2 and R3 (Prayogo et al., 2016). Then, the ones used to test the housekeeping gene were the Beta-actin primers namely; FA and RA (Prayogo, Wijayanti, Murwantoko, Kawaichi, \& Astuti, 2012).

$\mathrm{GnRH}$ and $\mathrm{GHH}$ genes with the results of $\beta$-Actin gene amplification used the Real-Time PCR to compare the number of RNA molecules amplified. The values obtained were then compared again with the fish treatment with various endosulfan concentrations using the Forlenza, Kaiser, Savelkoul, \& Wiegerties (2012) formula:

$\Delta \Delta \mathrm{Ct}$ (threshold cycle) $=\left(\mathrm{Ct}_{\mathrm{GnRH}}, \mathrm{GHH}^{-} \mathrm{Ct}_{\text {actin }}\right)$ sample- $(\mathrm{Ct}$ $\mathrm{GnRH}$ or $\mathrm{GHH}^{-} \mathrm{Ct}_{\text {actin }}$ ) Calibrator, $\mathrm{R}_{\mathrm{GnRH}}$ or $\mathrm{GHH}=2^{-\Delta \Delta \mathrm{Ct}}$

The fish were placed in a covered tray using a damp cloth and then blood was drawn from it with the use of a syringe slowly dipped into the caudal area near the base of the tail. The blood were collected into an eppendorf tube and placed in styrofoam by plugging in and allowed to settle for 30 minutes before being stored in an icebox. The blood samples were then centrifuged at a low speed of
$3500 \mathrm{rpm}$ for 15 minutes to separate the plasma and serum. The serum were placed inside the eppendorf tubes using micropipettes, and labeled according to the sample number and treatment types.

\section{Data Analysis}

The quantitative data of the GnRH-I, GnRH-II, $\mathrm{GHH}-\mathrm{I}$, and $\mathrm{GHH}-\mathrm{Il}$ genes in each treatment and exposure time were analyzed using One-way ANOVA. Data with significant difference were further analyzed using the Least Significant Difference Test (LSD).

\section{RESULTS AND DISCUSSION}

\section{GnRH Gene Expression in Male Hard-lipped Barb} Fish Exposed to Endosulfan

The effect of endosulfan in the fish reproductive activity was examined through the activity of the pineal-hypothalamus-pituitary-gonad shaft. In this case, the hypothalamic activity was evaluated based on $\mathrm{GnRH}$ gene expression (cGnRH and sGnRH). Prior to this study, the activity of GnRH gene expression, related to endosulfan in male hard-lipped barb fish, was unknown; hence, it was necessary to evaluate it in this study.

\section{cGnRH Gene Expression in Male Hard-lipped Barb Fish Exposed to Endosulfan}

There were fluctuations in the values of $c G n R H$ gene expression of male hard-lipped barb fish in each treatment from week 0 to 8 , as shown in Figure 1.

The RNA concentration of each sample was diluted to $10 \mathrm{ng}$ to make a cDNA. After this, the specific gene concentration of every sample was compared with the actin gene to measure the gene expression, using the delta $\mathrm{CT}$ equation. 


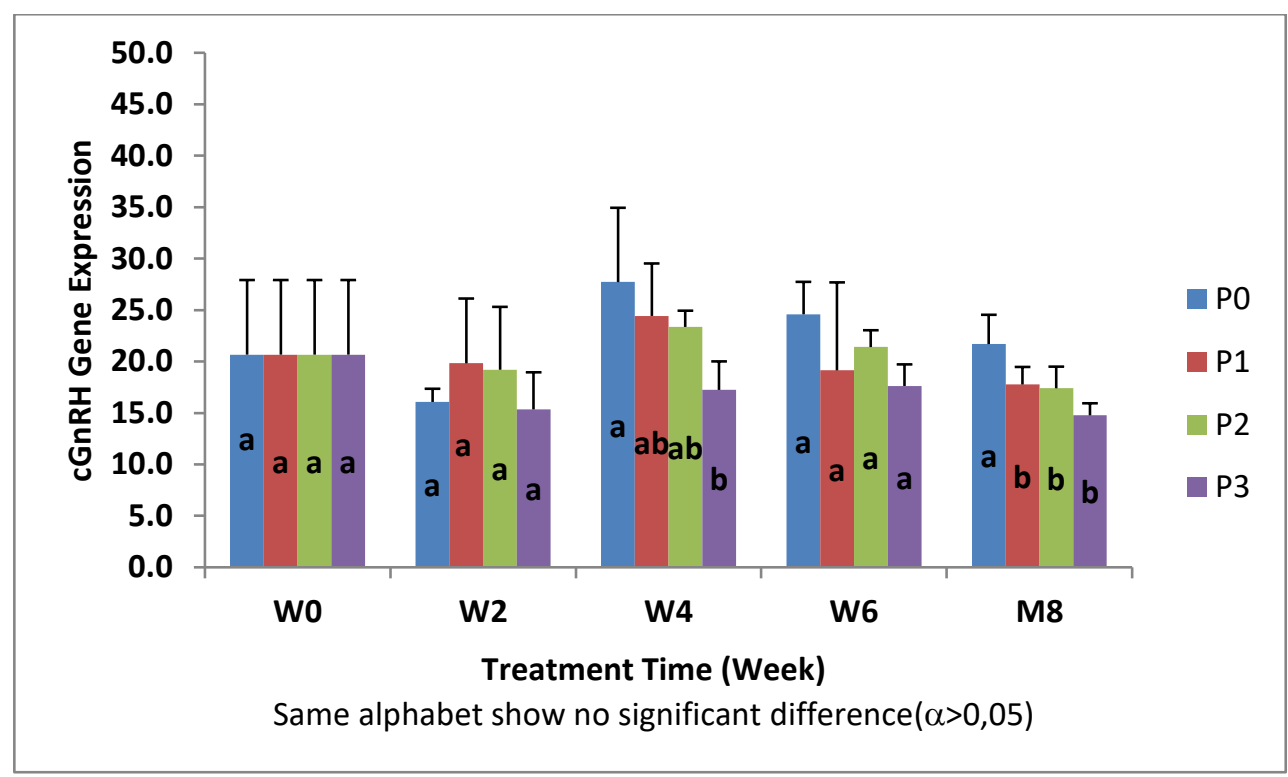

Figure 1. Mean and Standard Deviation Value of $c \mathrm{GnRH}$ gene expression of male hard- lipped barb after exposed to endosulfan concentrations (P0 = control, P1 $=0.88 \mathrm{ppb}, \mathrm{P} 2=1.76 \mathrm{ppb}, \mathrm{P} 3=2.64 \mathrm{ppb}$ ).

The results showed fluctuations in the concentrations of $\mathrm{cGnRH}$ gene expression in each treatment from week 0 to 8 , which then decreased over time. The value of $c \mathrm{GnRH}$ gene expression had the same concentration in all treatment at week 0 , put at 20.67, as shown in Figure 1. This was due to the fact that the fish have not been exposed to endosulfan at the stage.

The mean value of $\mathrm{cGnRH}$ gene expression at $2 \mathrm{nd}$ week of treatment ranged from 15.35 to 24.72 , as shown in Figure 1. However, there was no significant difference $(p>0.05)$ between the treatments. Hence, endosulfan treatment has not had a significant effect on the fluctuation of $\mathrm{cGnRH}$ gene expression in the 2nd week. This was probably due to antioxidant enzymes working to inhibit the endosulfan from producing excess Reactive Oxygen Species (ROS) in the hypothalamus and inhibit DNA damage, thereby allowing $\mathrm{cGnRH}$ to still be expressed at the highest concentration (2.64 ppb). This is consistent with studies on endosulfan exposure to zebra fish (Danio rerio). Based on the results, endosulfan concentration of $0.01 \mathrm{ppb}$ was able to slightly increase the activity of Catalase (CAT) and Superoksida Dismutase (SOD) as antioxidant enzymes, thereby eliminating ROS. Also, the increase in CAT and SOD activities is proportional to the increase in ROS, but at $10 \mathrm{ppb}$ concentration, the CAT and SOD activities decrease significantly because ROS production has reached excess levels, which could not be handled by CAT and SOD (Shao et al., 2012).

The mean value of cGnRH gene expression in the 4th week of treatment ranged from 17.24 to 27.72, as shown in Figure 1. There was a significant difference $(p>0.05)$ in the mean values between the control treatment and P3. This is an indication that the endosulfan has begun to have a major influence on the fluctuations in $\mathrm{cGnRH}$ gene expression in the 4th week. This was contrary to the results of the study conducted by Piazza et al. (2015). Based on the study, the exposure of toxic materials such as endosulfan for 30 days to larval fish of Cichlasoma continuously had no significant effect on the expression of the GnRH-II gene.

Then, the mean value of $c \mathrm{GnRH}$ gene expression in the 6th week of treatment ranged from 17.62 to 24.59, as also shown in Figure 1. Also, there was no significant difference ( $p>0.05)$ between the treatments. This could be as a result of variations in response by the experimental fish.

Lastly, the mean value of cGnRH gene expression in the 8th week of treatment ranged from 14.40 to 21.70 , as shown in Figure 1. Then, there was a significant difference $(p<0.05)$ between the treatments, especially between control and other treatments P1, P2, and P3. This was also due to the fact that endosulfan treatment in the 8th week had a major influence on the fluctuation in $\mathrm{cGnRH}$ gene expression. This is because the higher the levels of endosulfan which enter the blood and brain, the more the protein synthesis is inhibited, thereby reducing the gene expression and reproduction in fish. According to Gharaei et al. (2010), high levels of toxic substances such as endosulfan or heavy metals in the blood have the capacity of inhibiting the expression of the GnRH gene in the hypothalamus of beluga fish.

\section{sGnRH Gene Expression in Male Hard-lipped Barb Fish Exposed to Endosulfan}

Similarly, the results showed fluctuations in the concentration of the sGnRH gene expression, in each treatment starting from week 0 to 8 , which also decreased over time. The value of $s \mathrm{GnRH}$ gene 
expression was the same in all treatments at week 0 , put at 90.96, as shown in Figure 2. This was because the fish has not been exposed to endosulfan at the stage.

However, the mean value of $s G n R H$ gene expression in the 2 nd week of treatment ranged from 63.67 to 83.87, as shown in Figure 2. There was no significant difference $(p>0.05)$ between the treatments. Hence, treatment with endosulfan has not had a significant effect on the fluctuation in the decreased sGnRH gene expression. The results are in accordance with the research, which showed that the accumulation of heavy metals in the body of milkfish had no significant ( $p>0.05)$ influence on metabolism and protein synthesis of the fish after 2 weeks of exposure (Prabowo, 2005).

The mean value of $\mathrm{sGnRH}$ gene expression in the 4th week of treatment ranged from 33.30 to 49.74 , as shown in Figure 2. In addition, the mean values were not significantly different $(p>0.05)$ between among the treatments except between control and P3. Hence, the exposure to endosulfan has had an impact on the instability in the expression of the $s G n R H$ gene in hard-lipped barb fish. This is because gene expression in fish is usually disrupted when exposed to toxic pollutants such as heavy metals. According to Ballatori (2002), heavy metals bind to sulfhydryl containing protein, thereby disrupting various cellular components and brain performance systems. One of the factors showing a decrease in the gene expression is the impaired brain performance system. Endosulfan is induced by a number of cellular responses and which then causes a disruption in protein synthesis during transcription and translation processes, thus, inhibiting the formation of microtubules.

The mean value of sGnRH gene expression in the 6th week of treatment ranged from 11.65 to 22.67 , as shown in Figure 2. There was a significant difference $(p>0.05)$ in the average values in the treatments, especially between control and other treatments $\mathrm{P1}, \mathrm{P} 2$, and $\mathrm{P} 3$. This is because the time of exposure in the 6th week has had a major influence on the fluctuations in decreased sGnRH gene expression. Usually, the higher the levels of endosulfan entering the blood and brain, the more the gene expression and reproduction are inhibited in the fish. According to Gharaei et al. (2010), high levels of heavy metals such as $\mathrm{HgCl}$ in the blood have the capacity of inhibiting the expression of the $\mathrm{GnRH}$ gene in the hypothalamus of beluga fish. Heavy metals in the water enter the body of the biota through the respiratory system, then into the bloodstream and the cell. Once in the body system, these metals could mimic the activity and workings of hormones, thereby creating equivalent effects. In the cell nucleus, heavy metals bind to the promoter region, thereby preventing the enzymes which help in DNA transcription from binding to that area. This disrupts DNA transcription, thereby preventing RNA translation. Consequently, the synthesis of $\mathrm{GnRH}$ producing proteins is inhibited, thereby reducing gonadotropin which regulates hormone production.

Then, the mean value of sGnRH gene expression in the 8th week of treatment ranged from 3.59 to 26.86, as shown in Figure 2. There was a significant difference $(p<0.05)$ in the treatments, especially between control and other treatments. This was due to the fact that the endosulfan exposure at that time has had a major influence on the fluctuations in decreased sGnRH gene expression. According to Vinodhini (2010), accumulation of heavy metals in the fish body is influenced by the accumulation in the organ, the nature of the organism, feeding, activity, and the ability to adapt to the metal itself.

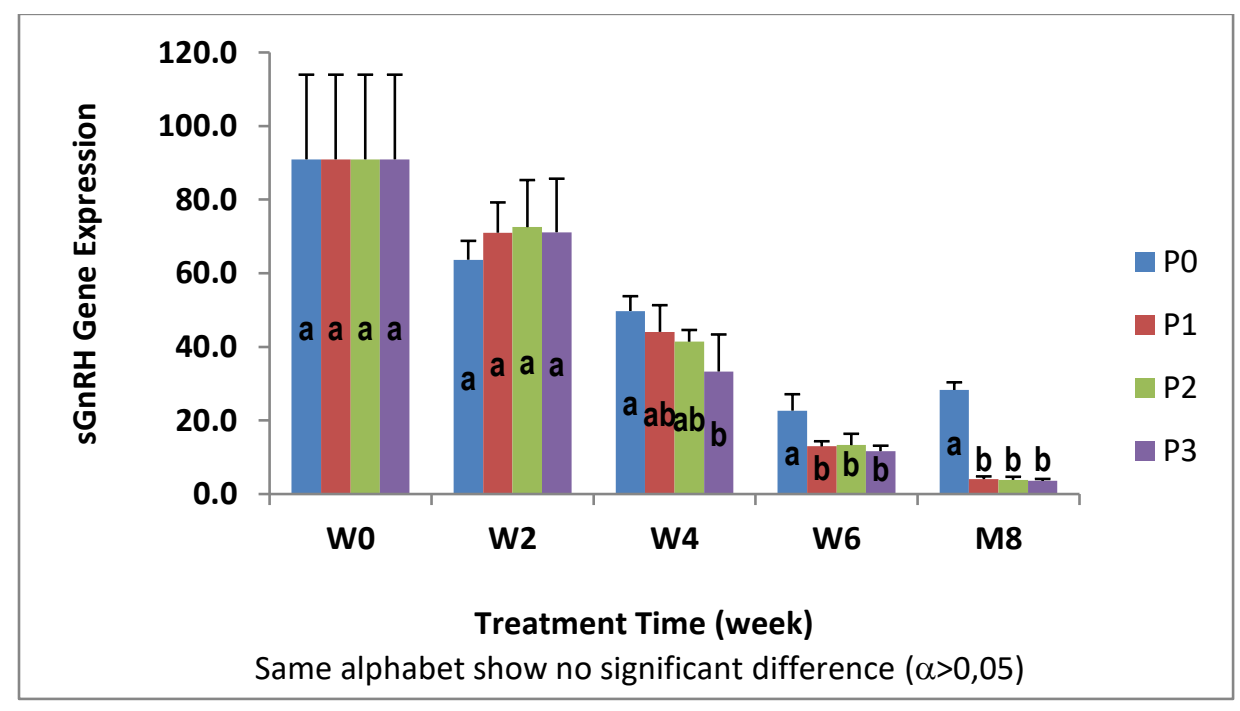

Figure 2. Mean and Standard Deviation Value of $s G n R H$ gene expression of male hard- lipped barb after exposed to endosulfan concentrations (P0 = control, P1 $=0.88$ ppb, P2 = 1.76 ppb, P3 = 2.64 ppb). 
G+H Gene Expression in Male Hard-lipped Barb Fish due to the Influence of Endosulfan

The effect of endosulfan in fish reproduction activities was observed through the PGP-Gonad axis activity. In this case, the hypothalamic activity was evaluated based on $\mathrm{GHH}$ gene expression ( $\mathrm{GHH}-\mathrm{I}$ and $\mathrm{G}+\mathrm{H}-\mathrm{II})$. Prior to this study, the activity of $\mathrm{GHH}$ gene expression in male hard- lipped barb fish associated with endosulfan was unknown, hence, the need to examine it in this study.

G+H-I Gene Expression in Male Hard-lipped Barb Fish

There was fluctuations in the value of the expression of $\mathrm{GHH}-\mathrm{I}$ gene in male hard-lipped barb fish from week 0 to 8, as shown in Figure 3 . The results also showed that there were fluctuations in the value of the expression of $\mathrm{GH}-\mathrm{I}$ genes among all treatments from week 0 to 8 . The expression of the $\mathrm{GHH}-\mathrm{I}$ gene had the same concentration in each treatment in week 0, put at 3.39, as shown in Figure 3. This was due to the fact that the fish has not been exposed to endosulfan at this stage.

The mean value of $\mathrm{GHH}-\mathrm{I}$ gene expression in the 2nd week of treatment ranged from 0.87 to 1.32 , as shown in Figure 3. There was no significant difference ( $p>0.05)$ between the mean values of the treatments. Hence, the endosulfan treatment has not had a significant effect on the fluctuation of $\mathrm{GHH}-\mathrm{I}$ gene expression in this stage.

In the 4th week, the mean value of $\mathrm{GtH}-\mathrm{I}$ gene expression in all treatments ranged from 1.08 to 2.26 , as shown in Figure 3. There was a significant difference $(p>0.05)$ in the mean values, especially between the control treatment and P3. This shows that the endosulfan treatment given at the 4th week has begun to have a major influence on the fluctuations expression of the $\mathrm{G}+\mathrm{H}-\mathrm{I}$ gene. Endosulfan destroys the endocrine system in the brain by causing disorders of estrogen, androgen receptors, and sex steroids. It inhibits sex steroids such as $17-\beta$-estradiol and progesterone through the inhibitory mechanism of cytochrome P450scc which converts cholesterol into pregnenolone for the synthesis of steroid hormones vital in the development of sperm follicles (Reyes, Rodríguez, Osuna, Del, \& Jaward, 2014). Endosulfan causes disruption of DNA replication in the cell cycle, thereby inhibiting cell poliferation. Also, the process of sperm development is disrupted whenever there is death of germ cells.

The mean value of $\mathrm{GH}-\mathrm{I}$ gene expression in the 6th week of treatment ranged from 1.50 to 1.89 , as shown in Figure 3. The mean value was not significantly different ( $p>0.05)$ among all treatments. This is due to the fact the endosulfan treatment has not had a major effect on the fluctuations in decreased $\mathrm{GH}-\mathrm{H}$ - gene expression, due to the variation in tolerance level of the experimental animals.

The mean value of $\mathrm{GH}-\mathrm{I}$ gene expression in the 8 th week of treatment ranged from 1.08 to 2.58 , as shown in Figure 3 . The mean value was significantly different $(p<0.05)$ among the treatments, especially between the control and the three others. This is because the longer exposure time and the high levels of endosulfan given in the 8th week had a significant influence on the fluctuation in the expression of the $\mathrm{GtH}-\mathrm{I}$ gene, thereby inhibiting protein synthesis. High levels of endosulfan in the water could diffuse into the fish's body and then to the bloodstream. Once in the blood, it inhibits the expression of the G+H-I coding gene by using the protein kinase $C$ pathway. Additionally, it induces the activity of protein kinase C, which increases the expression of 12-Otetradecanoly phorbol-13-acetate (TPA) responsible for suppressing the expression of the GHH-I gene.

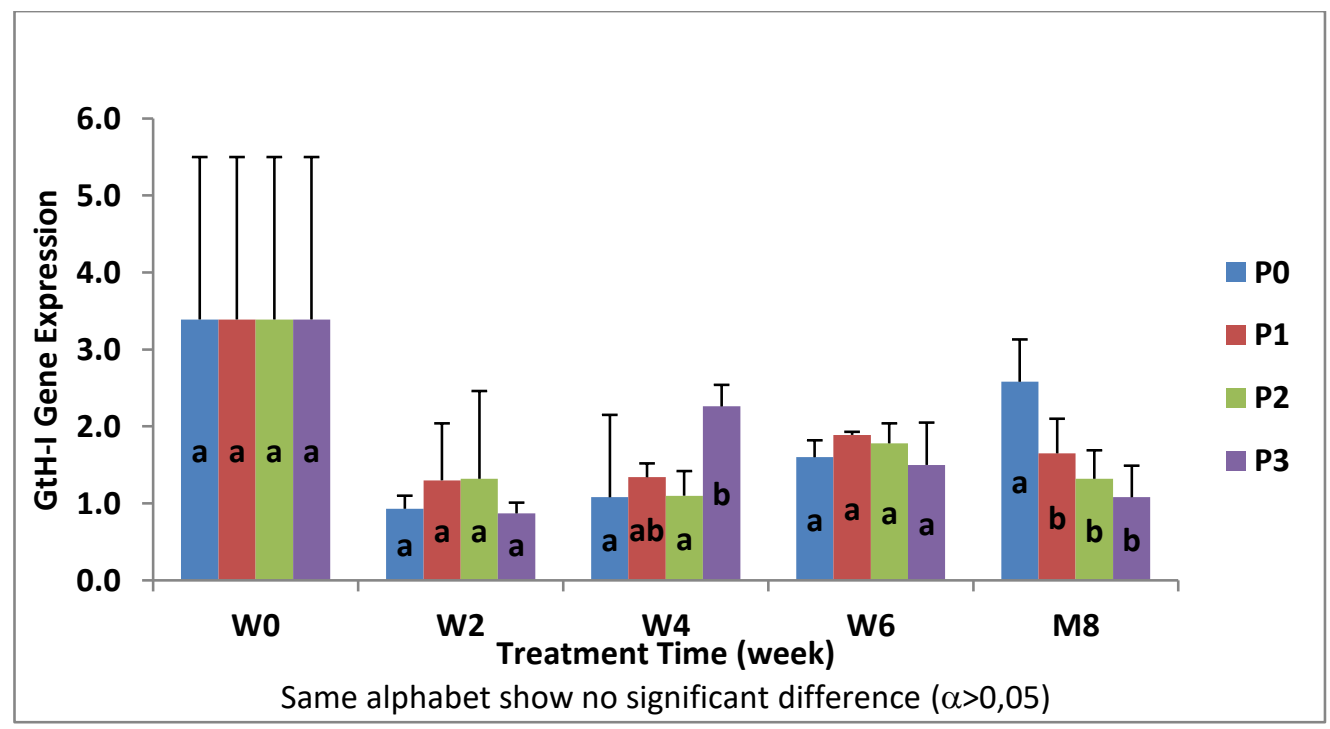

Figure 3. Mean and Standard Deviation Value of GHH-I Gene Expression in Male Hard-lipped Barb Fish after being Exposed to Endosulfan Concentrations (PO = control, P1 $=0.88$ ppb, P2 $=1.76$ ppb, P3 $=2.64$ ppb). 


\section{GHH-II Gene Expression in Male Hard-lipped Barb Fish}

There were fluctuations in the value of $\mathrm{GHH}$-II gene expression from week 0 to 8 , as shown in Figure 4. The results showed that there were fluctuations in the value of expression of $\mathrm{GHH}-\mathrm{Il}$ gene in male hardlipped barb fish among all treatments from week 0 to 8. The expression of the gene was the same in week 0 in all treatments, put at 78.82, as shown in Figure 4. This is because the fish has not been treated with endosulfan at this stage.

In the 2 nd week of treatment, the mean value of $\mathrm{G}+\mathrm{H}-\mathrm{Il}$ gene expression ranged from 27.62 to 57.99 , as shown in Figure 4. The mean value was not significantly different $(p>0.05)$ among treatments. Hence, the endosulfan treatment has not had a significant effect on the fluctuation in the expression of the G+H-Il gene. This is consistent with the results of the research conducted by Siregar and Prayogo (2017), which reported that exposure of the fish to mercury chloride $(\mathrm{HgCl})$ had no significant influence on the expression of its $\mathrm{GHH}-\mathrm{Il}$ gene. According to Taufik, Supriyono \& Nirmala, (2009), as well as Taufik and Setiadi (2012), the lowest concentration of endosulfan exposure in carp was $1.4 \mu \mathrm{g} / \mathrm{L}$. In addition, the $\mathrm{LC}_{50}-96$ hour value in this study was $5.87 \mu \mathrm{g} / \mathrm{L}$, lower than the results obtained by Koesoemadinata (2000) which was $12.9 \mu \mathrm{g} / \mathrm{L}$. The same study was carried out on cGnRH-II gene expression and the results showed no significant difference. The $\mathrm{GnRH}$ gene expression value that was not significantly different due to endosulfan exposure had same effect on the $\mathrm{G}+\mathrm{H}-\| ß$ value. This is because $\mathrm{GnRH}$ stimulates the pituitary gland to produce the hormone $\mathrm{G}+\mathrm{H}-\| l \beta$ (Kusuma, Marhendra, Aulanni'am \& Marsoedi, 2012). Then, the mean value of $\mathrm{GHH}-\mathrm{Il}$ gene expression in the 4 th week of treatment ranged from 14.26 to 27.97 , as shown in Figure 4. There was no significant difference $(p>0.05)$ in the mean values among the treatments except between control and P2. This is because the time of endosulfan exposure had a major influence on the fluctuations in decreased $\mathrm{GtH}$ II gene expression at this stage. These results are consistent with the research of Siregar and Prayogo (2017), which showed that exposure to mercury chloride $(\mathrm{HgCl})$ had no significant effect on the expression of $\mathrm{GH}-\mathrm{H}$ II gene between the control and treatment groups in male hard-lipped barb fish at the 4th week. In addition, the concentration of endosulfan treatment used for sublethal toxicity tests was classified as low at 15,30 and $45 \%$ of the $L C_{50}$ 96 hour value, while the standard treatment concentration used for the sublethal toxicity test was 20, 40 and $60 \%$ of the $\mathrm{LC}_{50}-96$ hour value (Ansari \& Ansari, 2014).

The mean value of $\mathrm{GHH}-\mathrm{Il}$ gene expression in the 6th week of treatment ranged from 14.55 to 17.24 , as shown in Figure 4. The mean value was not significantly different ( $p>0.05$ ) among the treatments, indicating that endosulfan treatment did not have a significant effect on $\mathrm{G}+\mathrm{H}-\mathrm{Il}$ gene expression in the fish. This was due to low concentration of endosulfan, i.e LC $50-96$ hours value in this study, which was $5.87 \mu \mathrm{g} / \mathrm{L}$, lower than the value obtained by Koesoemadinata (2000), which was $12.9 \mu \mathrm{g} / \mathrm{L}$. The same study was conducted on cGnRH-II gene expression and the results showed no significant difference. The $\mathrm{GnRH}$ gene expression value, which was not significantly different due to endosulfan exposure, also had the same effect on $\mathrm{GHH}-\mathrm{Il}$ value. That is because $\mathrm{GnRH}$ stimulates the pituitary gland to produce the G+H-II hormone (Kusuma et al., 2012).

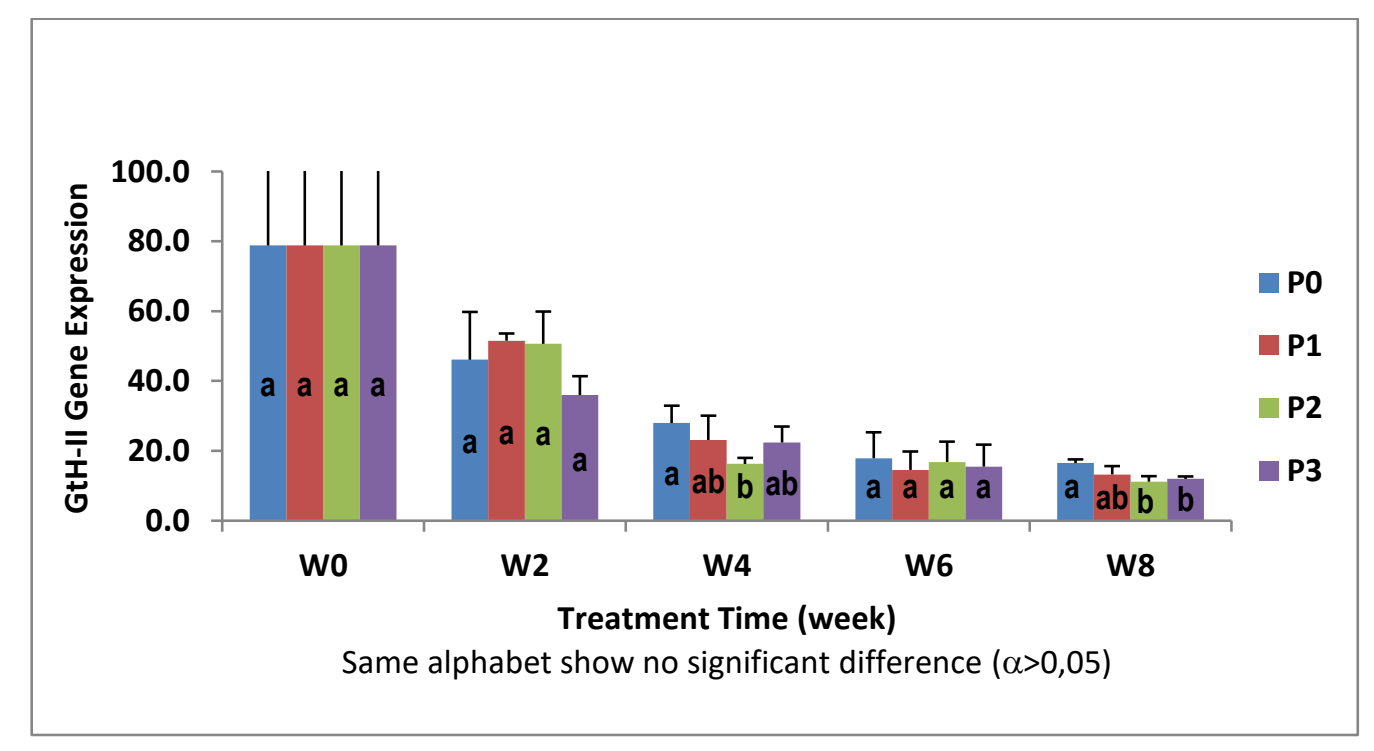

Figure 4. Mean and Standard Deviation Value of G+H-II gene expression in male hard-lipped barb fish after being exposed to endosulfan concentrations ( $\mathrm{PO}=$ control, $\mathrm{P} 1=0.88 \mathrm{ppb}, \mathrm{P} 2=1.76 \mathrm{ppb}, \mathrm{P} 3=2.64 \mathrm{ppb}$ ). 
Finally, the mean value of $\mathrm{GH}-\mathrm{H}$ gene expression in the 8th week of treatment ranged from 11.51 to 15.14, as shown in Figure 4. The average value was significantly different $(p<0.05)$ among the treatments, especially between the control and treatments P2 and P3. This was due to the fact that the exposure to endosulfan at the 8th week had a major effect on GHH-ll gene expression in the fish could be caused by the endosulfan half-life. According to Da Cuna et al. (2013), the half-life of endosulfan in water is 75 days, hence, its toxicity at 8th week would have begun to go on the decline.

\section{CONCLUSION}

Based on the results, it could be concluded that endosulfan inhibits cGnRH, sGnRH, GHH-I and GHH-II gene expression in male hard-lipped barb fish after 8 weeks of treatment with endosulfan. Furthermore, endosulfan affects the gene expression involved in the fish reproductive system.

\section{REFERENCES}

Ansari, S., \& Ansari, B.A. (2014). Temporal variations of CAT, GSH, and LPO in gills and livers of zebrafish, Danio rerio, Exposed to Dimethoate. Archives of Polish Fisheries, 22 : $101-109$.

Astoviza, M.J., Cappelletti, N., Bilos, C., Migoya, M.C., \& Colombo, J.C. (2016). Massive airborne endosulfan inputs related to intensive agriculture in Argentina's Pampa. Chemosphere, 144 : 1459-1466.

Ballatori, N. (2002). Transport of toxic metals by molecular mimicry. Environmental Health Perspectives, 110 Suppl 5 : 689-694.

Ballesteros, M.L., Miglioranza, K.S.B., Gonzalez, M., Fillmann, G., Wunderlin, D.A., and Bistoni, M.A., (2014). Multimatrix measurement of persistent organic pollutants in Mar Chiquita, a continental saline shallow lake. Science of the Total Environment, 490 : 73-80.

Bashir, N.H.H. (2019). Pesticide Accused of being Endocrine Disruptors. EC Pharmacology and Toxicology ECO.02 : 07-11.

Chakrabarty, S., Rajakumar, A., Raqhuveer, K., Sridevi, P., Mohanachary, A., Prathibha, Y., Bashyam, L., Dutta-Gupta, A., Senthilkumaran, B., 2012. Endosulfan and flutamide, alone and in combination, target ovarian growth in juvenile catfish, Clarias batrachus. Comparative Biochemistry and Physiology. C 155 : 491-497.

Chatterjee, R. (2016). Estimation of endosulfan toxicity on blood biochemistry of channel catfish Clarias batrachus Linn. South Indian Journal of Biological Sciences 2016; 2(4) : 445-450.

Carvalho, F.P. (2017). Pesticides, environment, and food safety. Food and Energy Security 2017; 6(2): 48-60.
Da Cuna, R.H., Pandolfi, M., Genovese, G., Piazza, Y., Ansaldo, M., \& Lo Nostro, F.L. (2013). Endocrine disruptive potential of endosulfan on the reproductive axis of Cichlasoma dimerus (Perciformes, Cichlidae). Aquat. Toxicol, 126 : 299-305.

Ditjen PSP (Directorate General of Agricultural Infrastructure and Advice). (2016). Agriculture and forestry pesticides. Ministry of agriculture of the republic of Indonesia. Jakarta.

Du, H., M. Wang, L. Wang, H. Dai, M. Wang, W. Hong, X. Nie, L. Wu and A. Xu. 2015. Reproductive toxicity of endosulfan: Implication from germ cell apoptosis modulated by mitochondrial dysfunction and genotoxic response genes in Caenorhabditis elegans. Toxicological Sciences Advance Access published Februari. 92: 1-34

Forlenza, M., Kaiser, T., Savelkoul, H. F. J. \& Wiegerties, G. F. (2012). The use of real-time quantitative PCR for the analysis of cytokine mRNA levels. Cytokine Protocols, Methods in Molecular Biology, 820. Springer Science.

Gharaei, A., Mahboudi, F., Esmaili-Sari, A., Edalat, R., Adeli, A., \& Keyvanshokooh, S., (2010). Molecular cloning of cDNA of mammalian and chicken II gonadotropin- releasing hormones ( $\mathrm{mGnRH}$ s and $\mathrm{cGnRH}-\mathrm{II}$ ) in the beluga (Huso huso) and the disruptive effect of methylmercury on gene expression. Fish Physiology and Biochemistry, 36 : 803-817.

Gore, A. C., Crews, D. (2009). Environmental endocrine disruption of brain and behavior. Elsevier Inc. Austin.

Guo, F.Z, Xu, Y., Ren, L.H., Zhang, J. Zhang, F., Duan, J., Zhou, X.Q. \& Suna, Z.W. (2017). Endosulfan induces apoptosis by activating the negative regulation pathway of cell cycle and eath receptor pathway in spermatogenic cells. Toxicology Research, 6 : 223-231.

Han, Z., Jiao, S., Kong, D., Shan, Z. \& Zhang, X. (2011). Effects of $\beta$-endosulfan on the growth and reproduction $f$ zebrafish (Danio rerio). Environmental Toxicology and Chemistry, 30, $11: 2525-2531$.

Koesoemadinata, S. (2000). Acute Toxicity of endosulfan, chlorpyrifos, and chlorphluazuron insecticides in three types of freshwater fish and giant prawns. Jurnal Penelitian Pendidikan Indonesia, 4 (3-4) : 3643

Kusuma, P.S.W., Marhendra, A.P.W., Aulanni'am, \& Marsoedi. (2012). Mechanism of the release of the gonadotropin hormone (GHH-II) catfish (Clarias sp.) after laserpunktur induction at the point of reproduction. Indonesian Journal of Science and Technology, 14 (3) : 209-215.

Pandolfi, M., Lo Nostro, F.L., Shimizu, A., Pozzi, A.G., Meijide, F.J., \& Rey, V.G. (2006). Identification of immunoreactive FSH and $\mathrm{LH}$ 
cells in the cichlid fish Cichlasoma dimerus during the ontogeny and sexual differentiation. Anatomy and Embryology, 211 : 355-365.

Piazza, Y.G., Pandolfi, M., \& Lo Nostro, F.L. (2011). Effect of the organochlorine pesticide endosulfan on GnRH and gonadotrops cell populations in fish larvae. Archives of Environmental Contamination and Toxicology, 61: 300-310.

Piazza, Y., Pandolfi, M., Da Cuna, R., Genovese, G., \& Lo Nostro, F. (2015). Endosulfan affects $\mathrm{GnRH}$ cells in sexually differentiated juveniles of the perciform Cichlasoma dimerus. Ecotoxicology and Environmental Safety, $116: 150-159$.

Prabowo, R. (2005). Cadmium Accumulation in Milkfish. Mediargo, $1(2): 58-74$.

Prayogo, N. A., Wijayanti,G. E., Murwantoko, Kawaichi, M., \& Astuti, P. (2012). Effect of photoperiods on melatonin levels, the expression of cGnRH-II and sGnRH genes and estradiols level in hard-lipped barb (Osteochilus hasselti C.V.). Global Veterinaria, 8 (6) : 591-597.

Prayogo, N., Siregar, A. \& Sukardi, P. (2016). The disruptive effect mercurychloride $(\mathrm{HgCl})$ on gene expression of cGnRH-II, sGnRH, and Estradiol level in silver sharkminnow (Osteochillus hasseltii C.V.). Turkish Journal of Fisheries and Aquatic Sciences, 16 : 1003-1009.

Rehman, M.U, Mir, M.U.R, Ahmad, S.B.,Shakeel, S., Shah, M.Y., \& Bhat, S.A. (2016). Endosulfan, A global pesticide : A review of its toxicity on various aspects of fish Biology. 5, Issue 6, Oct Nov 2016; 17-26.

Reyes, J.G.G., Rodríguez, G.R.G., Osuna, M., Del, C.C., \& Jaward, F.M. (2014). Bioaccumulation and evidence of hormonal disruptions in tilapia fish (Oreochromis spp.) exposed to sublethal concentrations of Pesticides in Sinaloa, Mexico.

Shao, B., Zhu, L., Dong, M., Wang, J., Wang, J., Xie, H., Zhan, Q., Du, Z., \& Zhu, S. (2012). DNA damage and oxidative stress induced by endosulfan exposure in zebrafish (Danio rerio). Ecotoxicology, 21 : 1533-1540.

Siregar, A.S. \& Prayogo, N. (2017). The disruptive effect of mercury chloride $(\mathrm{HgCl})$ on gene expression of gonadotrophin hormones and testosterone level in male silver sharkminnow (Osteochilus hasseltii C.V.) (Teleostei: Cyprinidae). The European Zoological Journal, 84(1) : 436-443.

Siregar, A.S., Prayogo, N.A. \& Sulistyo, I. (2018). Effects of Disruptive Endosulfan on the expression of kisspeptin, GnRH, GHH and vitellogenin encoding genes in silver sharkminnow (Osteochilus hasselti C.V.) female. Final Report of LPPM Unsoed Institutional Research, Purwokerto.

Sukardi, P, Hana, H, Prayogo, NA, Sulistyo, I, Soedibya, PHT, Harisam, T, \& Winanto, T. (2018). A Lipid-walled microcapsule diet as co-feed for early feeding the Osphronemus gourami (Lacepede) larvae. Acta Scientiarum. Animal Sciences, 40, e38335. Epub June 11, 2018.https://doi.org/10.4025/actascianimsci. v40i1.38335

Taufik, I., dan Setiadi, E. 2012. Toksisitas serta potensi bioakumulasi dan bioeliminasi insektisida endosulfan pada ikan mas (Cyprinus carpio). Jurnal Riset Akuakultur. 7(1) : 131-142.

Taufik, I., \& Setiadi, E. (2015). Exposure of endosulfan insecticides at sublethal concentrations to haematological and histological conditions of carp (Cyprinus carpio). Journal of Aquaculture Research, 10 (1) : 109-115.

Taufik, I., Supriyono, E., \& Nirmala, K. (2009). Effect of endosulfan bioaccumulation on growth of carp (Cyprinus carpio Linn). Indonesian Aquaculture Journal, 8 (1): 59-65.

Thangadurai, P. and Suresh, S. (2014). Biodegradation of endosulfan by soil bacterial cultures. International Biodeterioration dan Biodegradation. 94: 38-47.

Vinodhini, R. (2010). Detoxifying effect of Nelumbo nucifera and Aegle marmelos on hematological parameters of common carp (Cyprinus carpio L.). Interdisciplinary Toxicology, 3(4): 127-131.

Watts, M. (2012). Endosulfan. Panap, pesticide action network asia \& pacific (2nd Edition).

Weber, J., Halsall, C.J., Muir, D., Teixeira, C., Small, J., Hermanson, M., Hung, H., Bidleman, T., \& Solomon, K. (2010). Endosulfan, a global pesticide: A review of its fate in the environment and occurrence in the Arctic. Science of the Total Environment, 408 : 29662984.

Wu, Y., He, Z., Zhang, L., Jiang, H., \& Zhang, W. (2012). Ontogeny of immunoreactive LH and $\mathrm{FSH}$ cells in relation to early ovarian differentiation and development in protogynous hermaphroditic ricefield eel Monopterus albus. Biology of Reproduction 86(3) 93 : 1-9.

Yoon, K., Kwackb, S.J., Kimc, H.S. \& Leec, B.M. (2014). Estrogenic endocrine-disrupting chemicals: molecular mechanisms of actions on putative human diseases. Journal of Toxicology and Environmental Health, part B. 17:127-174. 